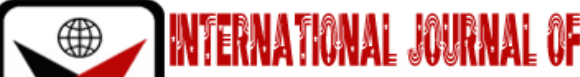 \\ בmRक
}

ISSN 2278-0211 (Online)

\section{Conflicts Resolutions and Impacts in Momo Division in the North West Region, Cameroon}

\author{
Achengwang Veronica Nwobeneyi \\ Teacher, Department of English, University of Yaounde 1, Cameroon \\ Dr. Fonjong Lucy Udikoh \\ Senior Lecturer, Department of Anthropology, University of Yaounde I, Cameroon
}

\begin{abstract}
:
Conflict is a process of human interaction as described by social conflict analysts. So is the case of conflicts resolutions and its impacts in Ngie, Momo Division of the North West region in Cameroon. This study dwells on literary and field data on conflict in Ngie. It demonstrates the contribution of conflict hold to the socio-cultural development of this subdivision experienced in the past until late. Notwithstanding this ill many are drawn back from the contemporary era as this could be seen as a cultural heritage since conflict is experienced at almost all levels from individuals in the home right up to the elites due to self-centeredness. In acquiring the necessary qualitative data, we used life-stories, interviews, focus groups and observations. The goal of this study is to measure the impact of retardation the society has witnessed and what prospects to integrate in the social system. Four villages with conflict problems were studied. Our study reveals that cultural contacts and information enhance social change. Though rural sustainable development is highly recommended there is need for unity to help in development.
\end{abstract}

Keywords: Conflicts, Resolutions, impacts

\section{Context and Justification of Study}

Conflict is a process of human interaction as described by social conflict analysts and occurs in all human societies but varies in degree and form of expression. Thus, conflict can be verbal or physical aggression which is recurrent or passive. It is as old as the human society, but its prevalence spread in Africa is typical of the $20^{\text {th }}$ and $21^{\text {st }}$ century human disaster. Some scholars have the same opinion that for a long time, Africa has been saddled and bogged down by alternating and continual conflicts both within and between states. This implies that Africa is meet head-on by internal (intra) and external (inter) conflicts. Like Ting-Toomey (1985, p.72) conflict could be seen as a form of intense interpersonal and/or intrapersonal dissonance between two or more interdependent parties based on incompatible goals, needs, desires, values, beliefs, and/or attitudes. Meanwhile, Rahim and Magner (1995, p.722) regard conflict as an interactive process manifested in incompatibility, disagreement or dissonance within or between social entities.

Remarking on the conflict state of affairs in Africa, Birgit Brock-Utne (1996) noted that 'Africa silhouette the highest figures of brutal conflicts'. This was clear-cut by Tangie when she writes that 'Africa is the world's leading theatre of conflicts'. Though, it is often said that Cameroon is an Island of peace in unrest Central African Region, it has gotten its own share of conflicts in different parts of the country which shoot from ethnic diversities, thus, resulting in intra-ethnic and inter-ethnic conflicts. These conflicts are many in the North West Region of Cameroon goaded by various factors. Presented writing shows that many intra-ethnic and inter-ethnic conflicts have colonial precursor, linking past and colonial heritage. This feature, as well as the unequal allocation of inadequate resources in combination with many others, was accountable for conflicts in the North West region like those of the Ngie People from 1940 to 2000.

In Chinua Achebe's Arrow of God, we see conflict between and modernity and tradition where Mathieu is a priest and traditional practitioner at the same time. By this we are saying that a conflict occurs when there is a differentiation in opinion. In the framework of anthropologists, conflict is a rivalry between at least two parties over incompatible desires, values, interests and or aims. A party in this sense could be a person, a family, a lineage, the whole community, a clash of ideas, a political organization, a tribe or a religion. In supplementary it is an outcome of unsuited wellbeing or values flanked by different parties. In social know-how or sense, conflict is a fight back between individuals or collectivities over values or claims, status, power and scarce resources. The intentions of conflicting parties are not only to gain the desire values but to deactivate, hurt or get rid of their rivals. It also spurts whenever two or more persons or groups ask for the same object, occupy the same space or the same exclusive position. Or play mismatched role, maintain incompatible goal or assume reciprocally incompatible means for achieving their purposes A. Schmid (1978) reinforce this observation in a more simplistic way when he says that conflict is 'the struggle between men for power, status, identity and even resources especially land, moving progressively from one stage to another. 


\section{Location of Study Area}

Ngie is a sub division found in Momo Division, of the North West region of Cameroon. Like most parts of the North West region, the landscape is very mountainous and slopes from north to south. This renders settlement, movement and agricultural activities difficult. Irrespective of all these topographic difficulties, human activities linked to its cultural touristic nature can still be felt. According to RGPH 2005, Ngie has a population of 17.697 inhabitants with a total of 8637 men and 9060 women respectively. It is divided into 19 villages. With the family being the basic unit of production and consumption, there are differences in descent roles and types. That notwithstanding, the family head is the father who is assisted by the mother, with the first then the second child in order of birth. It is a patrilineal and patrilocal group. Besides, the extended family is a composition of families grouped around the family. However, extended families may not necessarily live together in the same place due to social mobility or migration. Meanwhile, the nuclear family is made of the father, mother and children while an extended family is made up of the father, mother, step brothers and sisters, cousins, aunties and uncles. Politically, there exist both the traditional and the modern systems with the political system not having a place for the woman. In the meantime, there are priests who are custodians of the land as well as the spiritual leaders. While chiefs and elders are the custodians of the customs and traditions of the community and serves as entry points and liaisons between the community and outsiders.

In education, both formal and informal education exists. Parents provide informal education at home about their environment and what the community expects of their children and strangers while formal education is taught in schools. In the past, female formal education was not considered important because society saw that their only role is childbearing and home management. However, with information and awareness, couple with capacity building, gender equality is becoming a way of life for many communities not leaving out Ngie, to that effect, the community is getting to know the indispensable role of a woman in sustainable development through education.

As outcome, some focal points on some socio-cultural inheritance on the Ngie clan in Momo Division are gender roles, agriculture, and conflict to mention a few. In the framework of 'indigenous conflicts' (Intra-ethnic conflicts) and decision between the Ngie people, we can likewise measure inner conflicts and leadership weakness amongst the Ngie people. This is the basis why conflict has been over mentioned as it has formed enormous impact on the Ngie community which includes: limitations, underdevelopment and failure in social relations among members.

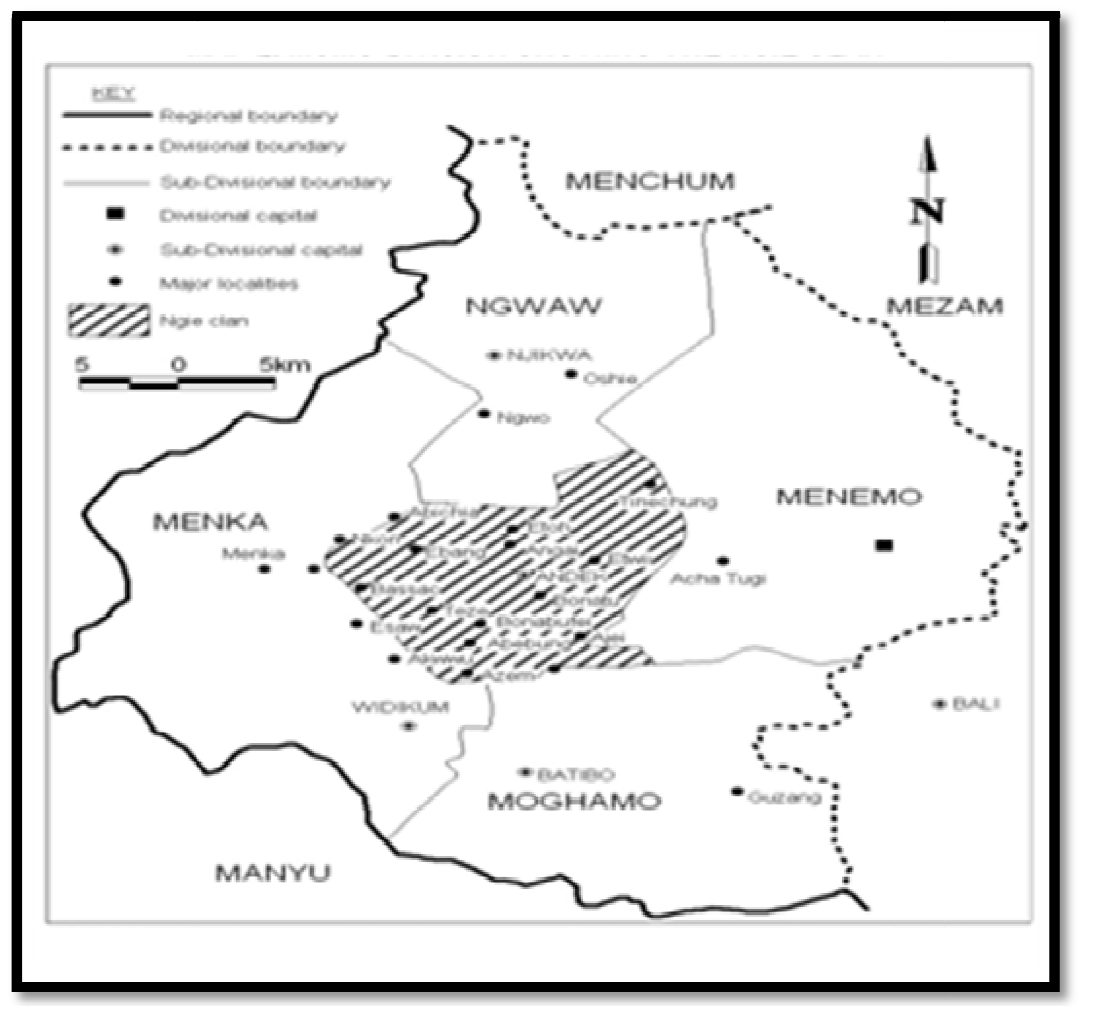

Figure 1: Map 2 MomoDivision Showing the NGIE Clan

\section{Methodology}

Our study is basically an ethnographic study which describes and examines factors pertaining to conflict as the pursuits of incompatible goals by individuals, villages or groups of people within the named community. Such practice has been noticed as a struggle, argument, disagreement, opposition, fight and quarrel amongst or between the Ngie people over ownership of scarce resources such as land, location of social services like schools, and administrative units. It is also a quarrel between farmers and graziers over land and crop destruction, or a disagreement between people on political representation. In addition, conflicts amongst the Ngie people could also arise from a dispute over family property or chieftaincy. In this reasoning, conflict is not necessarily a war (which requires the use of dangerous weapons), but it includes other forms of confrontation with less or more concentration of violence. The main objective of this study is to understand how public opinions could help erase past conflict impacts to push development in the Ngie community. We 
obtained data from primary and secondary sources, from a target population whose ages were 40years and above. This involves people who were born in the situation and seeing the impact on the younger generation and their progeny. Most of our informants were interviewed for at most one hour and focus groups were held with at least 06 persons for an hour respectively. Informants had the freedom to talk on without divergence from the research trend. We worked with 100 persons who were also of different religious backgrounds such as Catholicism, Islam, Protestantism, and paganism but were predominantly from the Protestant faith. Some of the professions of informants included: teaching, farming trading medical attendance, housewifery, herbalist, officer and drivers. Their different professional and demographic backgrounds permitted us to understand the awareness of the respondents on the level of information on conflict, manifestation and measure to resolve these disharmonies. In-depth interviews, participant's observations, indirect observation were used to gather information. We chose periods of transhumance like summer holidays and end of years for our research programme so that we could gain concrete information from many people who usually filled the localities.

\section{Background Information and Case Studies}

We shall illustrate some sources and cases of conflict in our research. These include:

\subsection{Case Study I: Land Conflict between Andek and Teze}

Land conflicts in Ngie Sub Division could be explained given the different periods they took place. For example, the land conflict between Andek and Teze was originated by the Teze people who farmed lands belonging to the Andek people while that of Angong-Abebung was due to claims made by both parties on ownership of land in Angong.

Looking at the Ngie community in line with issues of conflicts, Ayong Peter, Abanasom Shadrach and AzobiVicent list some aspects that led to conflicts amongst the Ngie people at different times. Ayong Peter narrows his work to Andek and Teze villages. Here he pointed the fact that these two villages were in conflicts since the dawn of the post-colonial period rival for government institutions predictable for Ngie area. His indications were on the proceedings of politicians and leading people of Teze village for requesting the natural undeniable geographical centrality of Andek village. This is acknowledged by the greater part of other Ngie villages to be the lead of administrative activities in Ngie.

\subsection{Case study II: Political Conflict}

Equally he shows how these politicians tried to use all manners of reserved means such as blackmails, writing of petition letters and manipulations of the administration to take over a number of mission and government institutions earmarked to be position at Andek. The expansion of these actions brought the two villages into sharper focal point which nursed extreme dislike. Consequently, this led to the Upper-Lower Ngie difference characterized by the split of the Ngie community into two contrasting camps. The author's work is valuable to this fill up in that it points out some of the factors that led to the Upper-Lower Ngie discrepancy, but the collision of such a crisis and how it was redressed can be traced.

Abanasom giving light on conflict between Andek and Teze handled the antagonistic affiliation from land curiosity perspectives that was provoked by many factors. His writing portion uses names like Akan (Teze village) and Anjong (Andek village) to coat the image of two Ngie villages, which decline to entirely work together owing to greed for each other and the chase for supremacy in the clan. Stipulating that Andek and Teze have originated from Dudum, he notes that these villages split a common land border line set apart with a rich fruitful (the ancestral agricultural land). He patents out that the isolated grounds of this conflict were surrounded to the authority struggled involving the chiefs. This is on the problem of who ought to be acknowledged as the Ngie clan head. The move of the Ngie Native court from Teze to Andek brought more anguish into the state of affairs. He comments that the buildup of these grievances pressed the 'Akan people' (Teze) to invade Andek land and seized all the farm equipment of their women, thus, detached inter-village collaboration connecting them. It should be famous that Abanasom's work is a prose description which blends real facts and fictions. This idea suggested in his work was an inspiring feature for the researcher to come across the actual actors of the conflict, and also to build a sequential report of the conflict found on chronological facts.

\subsection{Case Study III: Agricultural Conflict}

Centered on the milieu and how the Ngie people have custom-made to it, AzobiVicent reviews the farmer-grazer relation in Ngie asserting that the openness of grassland shrubbery and the complimentary climate has upbeat farming. This has encouraged farming and grazing in Ngie particularly in Etwii, Angai, Etoh, Ajei and Andek. His case is that agriculture and grazing has not been victorious in Ngie area due to conflict caused by the growing number of cattle in the Sub Division specifically where farming activities pilot. This is also as a result to climate change that influence animal pastures, thus forcing herders to move with the cattle from place to place. At times they go near farmlands where these animals demolish crops ensuing to conflicts involving farmers and grazers.

\subsection{Case Study IV: Ideological Conflict}

Another area of conflict is ideological conflicts which are generally disagreements and these are not new in the field of conflict studies. The two great powers; America and Russia had once experienced this man-made conflict fought with the displaying of economic weapons. In relation to this study, ideological conflict in Ngie is very much persuaded by politics and selfish interest. It comes into view as a result of Ngie politicians and some dominant elites who wanted to make gain for their particular villages. It was also predisposed by supremacy conviction. The conflict separated Ngie people into Upper and Lower camps which for over two decades patent serious struggle to influence and host imperative social and political services intended for Ngie. 


\section{Discussions}

\subsection{Origin, Manifestation of a Selected Land Conflict (Abebung and Angong)}

Historically, the British colonial period, witnessed major conflicts amongst the Ngie people and these were first cases which were documented from 1940. Eventually it was unusual, why? because it was the first time, that the clan was troubled by serious internal intimidation. Thus, contrasting the previous years where the people had faced antagonism from outsiders like the Balis and the Germans. Before this time, there was no village chief with intentions to overcome any villages or families as the paramount authority. As a result, there were no inter-village disputes for domination since each village in Ngie was independently settled and paid no allegiance to any higher village. This is contrary to the Nso and Kom kingdoms where there is a king.

That notwithstanding, the British on arrival in Ngie thought that the Germans system of organization should be rebuild since the Germans classification could have awful effects on their administration. By so doing they began to maneuver the domestic affairs of Ngie by suggesting the idea of a clan head which in some way led to the surfacing of clash in the clan. The most major conflicts shepherds in a new period of disagreement during the British colonial era were intravillage chieftaincy disputes and inter-village land conflicts. Actually, a case of chieftaincy dispute and two cases of intervillage land conflicts were traced during the British colonial episode, which impinge on the people's lives. To make mentioned are: the Azem chieftaincy dispute, the first Abebung-Angong land conflict, and the Andek-Teze land conflict.

Although the Ngie clan has undergone many areas of conflicts between villages we shall handle one major disagreement here which is that of the Abebung-Angong land conflict.

\subsection{Reasons for Conflict}

Though many factors contributed for the first land conflict between Abebung and Angong, one of the major reasons was the quarrel between them over patches of land found on the west bank of the Ono stream where the Angong people settled. According to the Angong people, they gave the Abebung people the land during pre-colonial period, whose opinion is not accepted by the Abebung people. Rather, they said the undecided patches of land are their property from the time they settled.

Meanwhile the two villages had lived from the time they established without a land conflict up to 1940. Of course, this is the time when serious differences over land began to be visible. These were the unprecedented behaviour of some people from both communities, by their non-acceptance of the Ono stream as the natural boundary by Abebung. Owing to the pursuit for farming land by the Abebung people, the challenge to be in charge of Andegechung, by the nature of their history of origin provoked dispute with their neighbours, the Angong people.

Subsequently, with the dealings of the two communities, they had farm lands on common field located in Angong. From official figures, there were about thirteen plots that were attributed to the Abebung people (Fieldwork 2014). Meanwhile, these patches of land were either in-between or closest to those that were owned by the Angong people and contained a variety of crops like cocoyams, beans, maize, raffia, and palms. Since both communities enjoyed this economic relation and farmed without problems.

Nevertheless, during the British colonial period, the high spirit of inter-village socialism and cooperation began to dissolve due to unprecedented behaviour, prejudice and detestation by some people. Some people from both sides nursed and harbored new lifestyle of differences that resulted to conflict. In 1940, the first land conflict broke out between AndoanoAbanyang of Angong and Ajugazum of Abebung and this led to a court case. When the court passed judgment on the case, it left the two parties with much frustration as their prospects were never met. The court decision instead created resentment among well-wishers of the two parties who became concerned in the issue than ever before. Consequently, this widened the possibility of conflicts which became an inter-village crisis rather than inter-persons disagreement.

Also, complex by behaviours of some Abebung people who were supposed to have continually harvested crops and palm nuts that were said to belong to Angong people and was provoked by the uncontrolled seizing of goats, dwarf cows and the burning of houses by the Abebung people at Umon and Akuangya quarters of Angong. All the things done by Abebung people forced the Angong people to retaliate. However, the Angong people immediately asked for the expulsion of Abebung people from their land because they believed that their opponents were undermining their position as the landlord. That's why they called for the exile of the Abebung people by force from farm lands which they had occupied on their settlement since pre-colonial time. Hard as the matter was, it became a severe land clash (Fieldwork,2014).

\subsection{Flashback}

The past linked to the origin of most ethnic groups, tribes, clans, villages and even families is always an unquestionable foundation of inconsistency particularly in the BamendaGrassfield of Cameroon. The reason is due to unclear verbal accounts given that it is handed from generation to generation by mouth. Such is an example of the situation of Abebung and Angong. It was eminent that the oral account about their starting point is blurred. To the Abebung people, they maintained that their ancestor Bungafughe was the forefather of the people of Angong and Ajei. This is to some extent is in line with Mr. Hook's report about their movement but it cannot be worth accepted since the Angong people dismissed such bond of beginning with the Abebung people (Hook, 1940). They somewhat traced their forefather directly from Ngiekum not Bungafughe; who is supposed to be one of Ngiekum's sons. In such situation, there is no requirement to accuse the two parties for protecting their origins because the history might have been indistinct by some people due to inevitable conditions or self-significance.

While this is a matter of the past and not land, the situation has considerable attitude on the land conflict between the two villages. Expressively, the Abebung people's notion that tolerating a demarcated boundary between them would 
have meant breaking aged historical ties with Angong. It should be acceptable that if one considered the reward of chronological ties during pre-colonial time especially among the states of the Western Grassfields of Cameroon, then it was but normal that the Abebung people should refused any boundary between them. This obviously intricate things and prepared the conflict long-drawn-out.

\subsection{Attempts to Amend the Land dispute}

The erratic disharmony over land between Abebung and Angong resulted to frequent abortive efforts to stop the fighting. Remember one of the reasons of conflict between the villages was because the patches of land located near Angong were fertile. Also, beyond, the disagreement on the boundary line as the Ono stream. Consequently, one major complexity was to set up a line or to distinguish the border line suitable to the two parties. In this esteem, numerous efforts were prepared by the administration and also by the courts to reconcile differences among persons as well as determined a satisfactory farm land limit among the two villages.

Attempts to handle this matter were in two faces: these involve the attempts made by the Divisional Court in Bamenda, and that of the local administration in Mbengwi. As far as the role of the courts, were concerned, some informants settled that the resolution notion were in progress by the Ngie Native courts meanwhile both villages assert defeat of the case in the native court but no document could support these declarations.

A negotiation means of solving the problem of dispute between the two villages was adopted by the Bamenda high court. By this esteem, the Bamenda high court made two registered cases concerning the land conflict between the Abebung and Angong. These courts suits were under the name of AndoanoAbanyang of Angong against Ajugazum of Abebung over pieces of land he declared belonged to him. The first was registered as case no 35/60, heard from 1940 to 1941 during which the claimant Andoano of Angong claimed the defendant Ajugazum of Abebung for unlawfully working on his farm. Following months of negotiations, the court prearranged a study which was conducted with the supervision of the Divisional Officer of Bamenda Mr. Thomas.

Based on the finding assignment of the focus group, Mr. Wood House conceded sentence no 48/53 yielding Atedong to the plaintiff and Ndong to the defendant. However, this decision did not meet the expectation of the plaintiff whom in 1962 was again claiming Ndong; the area formerly given to the defendant. To that effect he made new aver against Ajugazum but as the case went to the same court, it was examined and revealed that it was the same piece of land. The courts insisted that the decision of 1941 be maintained. Sorry to say, that both parties were unwilling to stand with the court decree as they were disgruntled with the verdict. This discontent is explained by the fact that AndoanoAbanyang sought the court to give him all the farms, while Ajugazum on his part preferred the one given to his antagonist in 1948. As a result, people from both sides began to feel bad with them as they sustained with the fight, which ultimately caused more war of words. Since both proof sturdy, the disagreement shoots up, thereby involving the administration to come in.

In order to keep peace as an obligation, the local Administration of Mbengwi, was concerned in resolving this quarrel from 1975 to1982 by taking vital actions. One of such measures was the issuing of a prefectoral order no.98/DM0/191/s.2/117, creating a commission of sixteen-man delegation that explored and dogged the border line among the two villages. This action undertaken by the Prefect of Momo Division was in agreement with the creation of the United Republic of Cameroon which certified and give power to the Senior Divisional Officer to form a commission for the resolution of disputes between governmental units or village communities. As stipulated in decree no.74/490 of the $17^{\text {th }}$ May 1974 as a way of maintaining law and order in Cameroon. The commission was chaired by Mr. J. N. Akale, the Divisional Officer for Mbengwi Central Sub Division meeting at his invitation in Mbengwi on the $20^{\text {th }}$ December 1975 and putting in place a plan of action. Representatives from both communities were invited, and during the meeting other things were discussed, and they were asked to present on paper aver over the disputed area and a sketch map each. A peace talk was scheduled from $17^{\text {th }}$ to $20^{\text {th }}$ of January 1976 by the commission then.

\subsection{The 1976 Peace Treaties}

Three peace talks were organized in Angong, Abebung and Andek respectively, with the commission performing as the intermediary compelling each party to pay attention while the other offered its testimonial of assert. Meanwhile, each party had the chance to cross inspect the claims given by the other. The two communities were traversed from the South to the North through the disputed areas in a bit to see where to establish the border line by the commission. After this tour, the commission and the parties met in a neutral ground in Andek where they relooked at some disturbing issues that came up before the implementation of the commission's judgment. Despite this verdict, there were still certainty that dissatisfaction as it had always been the case was likely to set back to the commission efforts as Pa Jacob Ajuazum; member from Abebung avoided the closing venue certainly in expectation of being unappreciative to approve the commission's verdict. In spite of his absence, the following statements represented the undisputed point of the commission about the clash that took place between Abebung and Angong over land. Among other things, the commission resolved that:

- Each village should incarcerate itself within the area it settled on since the time of their ancestors;

- The Ono stream is the documented limit between Angong and Abebung;

- Umon/Andegechung land belongs to Angong people-ending at a brook called Ugonodong. From that, individual rights of occupancy under the terms of Native Rights Ordinance were granted to individuals of Abebung owning farms in Angong by the chief of Angong with or without payment of traditional tributes...,

- It also stated that 'indiscriminate crossing of the Ono stream by Abebung is aggressive and the sole cause of the dispute as they farm as if in no man's land'. The Commission recommended that where Angong settled on their bank of this river is their land. 
These resolutions were signed and forwarded to the Minister of state in charge of Territorial Administration in a report dated $10^{\text {th }}$ April 1976 by the Senior Divisional Officer for Momo Division for definite decision. Minister Joseph Chongwan Awunti on the 8 th $^{\text {th }}$ September 1982 then signed an order no.214/A/MINAT/DOT validating the commission's report.According to article 2 of this ministerial order, 'the natural boundary between Angong and Abebung villages is determined by the Ono stream north to the south...' Article 3 in brief insisted that the boundary between the two villages should be materialized on the land by pillars bought at the expense of the two councils or collectivities.

The decision taken by the minister was very important as peace and order returned between the communities at least for some time. From 1982 to 1991, the local administration in Mbengwi ensured the total respect of the boundary between the two communities as prescribed in the above-quoted ministerial order to be implemented. However, this was short-lived as other disputes continued thereafter. Though the issue of conflict between the two communities continued of late, it is not the case now as formerly.

\subsection{Consequences of Measures Taken}

Despite the above measures there were still manifestations which led to destruction of property by the said villages as provided below. For, this was an absolute contradiction of the ministerial order of 1982 which has earlier fixed the boundary between Angong and Abebung at Ono stream. The court judgment, in fact caused displeasure among the Angong people. The situation resulted in many frustrations as the people of the two communities were prepared more than ever before to fight to the last persons. Although a motion reference No.BCA/8c/MS/ 2000 of $5^{\text {th }}$ April 2000 was filed in by Angong to annul the Judgment, violent demonstrations took precedence. The intensity of the crisis forced the chief of Angong to draw the attention of the President of the Commission on Human Right in Cameroon through a letter dated $6^{\text {th }}$ April, 2000. He also profited from the situation to ask the president to influence the release of two Angong people who were convicted. From April to August 2000, serious violent manifestations systematically took place which led to the burning of raffia palms, destruction of crops, looting of property mostly in Akuwusowai quarter in Angong. On 31 ${ }^{\text {st }}$ of July, the Abebung people beleaguered and seriously beat the Angong people who went to harvest their crops at Egwoh quarter. Similar retaliation came from the Angong people who also attacked and fought the Abebung people who went to harvest crops on their farms in Angong.

Also, serious destructive manifestation between Angong and Abebung took place in August as the conflict reached its peak. As a matter of fact, on $1^{\text {st }}$ August 2000 a large population from the Abebung village well-armed with cutlasses and sticks came out and ambushed the Angong people who were going to a funeral at Akuwusowai-Angong. The next day, during the early hours in the morning, an angry crowd of Abebung people massively turned out and matched to Akuwusowai quarter where they assaulted and shattered people's houses, property and the Presbyterian Church House worth about 20 million Francs CFA. Church properties were also carried away. Spoil was done in the compound of MessrsNjim Jacob Anjoh and Anonganyim Emmanuel and property carried away. Mr. AndonganyimTheophelusAngwombu (the quarterhead of Akuwusowai), MrAjeagah Elias, Mrs.Ajeagah Celine and Ajeagah Lynda were vehemently taken to Abebung where they were acutely tormented, injured and their property seized. Banana farm crops were heavily damaged in the farm of Mr. Ayong Samuel situated along the motor way passing through Akwusowai to Ajei.

On $3^{\text {rd }}$ August 2000, the Abebung people continued their attack of Angong, destroying crops, SNV/EU/STABEX plantain and cocoyam farm in Akuwusowai. Fowls were carried away from Mrs. Abenjang Frida who was bereaved, and Mourners were compellingly detached from the funeral ground. Those who partake in the demonstration were youths, women and men from Abebung and Angong. Most of them wrestle using sticks and stones to attack and wound their enemy. While some Angong people were vigorously taken to Abebung where they were held for several hours, the Angong people also succeeded in restraining some Abebung people. From the inquiry, it is obvious that most of the annoyance and attacks were instigated by the Abebung people. Even though they also fall out that it was the Angong people who goaded the violence by destroying crops on Abebung farms and attacking their women each time they went to harvest crops on their farms in Angong. It was however thanks to the intervention of the Gendarmes instructed by the Sub Divisional Officer for Ngie that the high violent demonstration of 2000 was brought under control.

\subsection{Impact of Conflict to the Community}

The impact of violent conflict and fragility on a country's society, economy and political governance is devastating and encompassing. The effects can be tangible and visible, including killed and injured civilians, destroyed or derelict bridges and wells, and damaged or inadequate health and education facilities. However, in order to counteract the negative or positive effects of conflict, appropriate conflict-handling styles have to be implemented. Conflict management is what people who experience conflict intend to do, as well as what they actually do (Van de Vliert, 1996). It refers to the strategies implemented by members aimed at reducing or solving conflict.

They can also be intangible, such as the collapse of state institutions, mistrust in government, the destruction of social relationships psychological trauma and pervasive fear. Addressing both types of effects are essential in conflictaffected and fragile contexts. The 'community' has often proven to be resilient in such contexts, providing survival and coping mechanisms for insecurity and fragility. Experience has shown that even in areas of sheer desolation, social life and organizational systems can readily re-emerge within community networks. (Pouligny, 2005) Growing attention has thus been paid in recent years to the adoption of community-based approaches to help address the extensive needs in conflictaffected and fragile contexts. Fragile contexts are situations in which 'state structures lack political will and/or capacity to provide the basic functions needed for poverty reduction, development and to safeguard the security and human rights of their population.' (OECD DAC, 2007) Conflict-affected contexts encompass situations prior to, during and after armed conflict. 
Therefore, during conflict, the level of development in a country is affected in a number of ways. Firstly, conflict is likely to disrupt the distribution of food and other resources to the population. It is argued that the main cause of the 1984 famine in Ethiopia was not drought or overpopulation, but the fact that the food could not be distributed to the people due to the sheer size of the country and the scale of the war which was going on at the time. Secondly, many services, such as schools, are devastated by conflict which can cause literacy rates to fall - an indicator which is often seen as the key to more widespread development. Besides, conflict can cause an imbalance in the population structure, as men of economic age are those most likely to be involved in the fighting. In relation to this, the impact of conflict has diverse considerably over time and from place to place within Ngie as the uprising has spread and intensified visibly and invisibly with different labeling of the areas affected by the conflict which have been put within themselves giving room to tense atmosphere that seek occasions for expression as indicated by an informant.

\subsection{Impact of Cultural Bequest on the Community}

However, looking at the legacy of Ngie cultural heritage, the following could be presented as socio- cultural impacts of the Abebung-Angong conflict. When we observed the economic impact of conflict on the Ngie community since the colonial days to what is at hand many informants comment it to barbarism and great loss. When questioned why they think as such, some replied that looking at the Angong - Abebung land disputes, it could be attributed to the fact that the seeds of Ungiekum their ancestor is an image of ungodly, genes since they could go as far as destroying church property. The economic loss involved could be illustrated as seen below.

\begin{tabular}{|c|c|c|c|c|}
\hline No. & Item & Unit & Value per Unit & Total Cost \\
\hline 1 & Church Building & 1 & 10.000 .000 & 10.000 .000 \\
\hline 2 & Liturgical Colours & 6 & 5000 & 30.000 \\
\hline 3 & Communion Cups & 4 & 1.500 & 6000 \\
\hline 4 & Concrete altar & 1 & 100.000 & 100.000 \\
\hline 5 & Long Benches & 20 & 5000 & 100.000 \\
\hline 6 & Modern Table Chair Benches & 50 & 20.000 & 1.000 .000 \\
\hline 7 & Musical Drums & 2 & 6000 & 12.000 \\
\hline 8 & Calling Drum & 1 & 15.000 & 15.000 \\
\hline 9 & Rattles Set & 1 & 5000 & 5000 \\
\hline 10 & Musical Bells & 2 & 5000 & 10.000 \\
\hline 11 & Crosses & 2 & 15.000 & 3000 \\
\hline 12 & Flower Stands & 2 & 3000 & 6000 \\
\hline 13 & Liturgical Books & 5 & 1.500 & 7.500 \\
\hline 14 & Church Hymnaries & 20 & 500 & 10.000 \\
\hline 15 & Mugaka Song Books & 20 & 500 & 10.000 \\
\hline 16 & Table Chairs & 5 & 6000 & 30.000 \\
\hline 17 & Plates & 14 & 500 & 7000 \\
\hline 18 & Plastic Cups & 20 & 300 & 6000 \\
\hline 19 & Spoons & 24 & 200 & 4.800 \\
\hline 20 & Baptism Basin & 1 & 1.500 & 1.500 \\
\hline 21 & Official Records and Files & 7 & 4000 & 28.000 \\
\hline 22 & Baptism Mat & 1 & 1.500 & 1.500 \\
\hline 23 & Bibles & 10 & 5000 & 50.000 \\
\hline 24 & Communion Cards & 50 & 20 & 10.000 \\
\hline 25 & Communion Elements & $1 \mathrm{pkt}$ & 1.500 & 1.500 \\
\hline 26 & General Labour and Pillar & - & - & 500.000 \\
\hline \multicolumn{4}{|c|}{ Grand Total } & $12.024 .300 \mathrm{frs}$ \\
\hline
\end{tabular}

Table 1: The Estimated Cost of the Destroyed Presbyterian Church Akuwusowai in Angong Source: Sub Divisional Archives Ngie; Reference No E30/04/112/2/254

These estimates were primed and presented to the Divisional Officer of Ngie Sub Division by the Presbyterian Church of Akuwusowai authorities to make sure those from Abebung who masterminded the demolition of Akuwusowai Presbyterian Church structure should pay for the renovation and paraphernalia of a new church house. This is besides the fact that generally, economic activities were disrupted, farm lands which contained crops were destroyed, domestic animals, fowls were carried away, raffia bushes were burnt, and trade and businesses were badly affected. All these amounted to several millions which could have improved the living standard of the people. Consequently, the community had incurred a number of impacts that play a significant role on the livelihood of the people.

\subsubsection{Livelihood Security}

A major part of activity, which shapes people's lives and livelihoods with very much connection to the impact of the advancement of conflict, is that of local government. The first concern of the Ngie in areas under their social and political control is to establish the apparatus of local government and their distinctive forms of law and order; to create People's Local Government at village and, where possible, at district level. In a war situation, the threat to life and 
appendage constitutes one of the most obvious threats to personal security and to the lives and livelihoods of ordinary Ngie man. The fear of physical insecurity and, even more so, from the security forces - who have found it difficult to distinguish between ordinary people and politicians, and the mass of ordinary Ngie people in the rural areas - affects far greater numbers and inhibits a whole range of economic, social and political activities, particularly those that involve travelling or coming together in specific locations. To that many people have been affected in this way in their different daily routine in the community.

\subsubsection{Relationships}

In Africa, just as in the Ngie community, family ties and community networking are always valued, upheld and reinforced. To that effect a dispute between diverse parties gives room to seek for reconciliation during the dispute settlement. This of course would involve supporters of the disputing parties and the elders meant to talk the matters through, relationships which are given prime attention. Such relations are out looked in line with the past, and the tense or current conflict, and then the aim would be to improve future relationships. Indirect relationships are analysed along with direct ones to see cross-stitching potentials, for example, if each of the disputing parties happen to be musicians, this commonality may be utilized as a converging factor. The fear of sorcery or divine punishment is also used to show what the breach of peace would bring upon the society and the conflicting parties under development.

\subsubsection{Food Culture}

In terms of disruption to agricultural output, careful analysis of the agricultural statistics at a local level might pick up the effect of disruption to production. But, given the margins of error known to plague the agricultural statistics and the usually considerable effect of weather and other conditions on local farming activities and outputs, it is unlikely that these would reveal any clear trend or even a sudden drop in the previous years or so, under whatever conditions. Apart from that some land appropriations with palm oil which is the main agricultural source of income were highly affected and with markets interruption, many could not sell to meet their daily needs. Consequently, some parents who depended on the sales of this product were unable to raised resources for their children education and other basic needs.

\subsubsection{Food Prices}

The impact of food supply and restrictions on food prices has not been evident at the national level. This because conflict is worst in remote areas (subsistence-dominated and disconnected from regional markets) and due to the above reason, some who even manage to have opportunities to sell make things difficult with high prices. This was due to the fact that they were very few supplies and suppression of networks in neigbouring towns and villages.

\subsection{General Slowdown in Economic Activity Reducing Non-Farm Employment Opportunities}

There was a general slowdown in economic activity, removing livelihood opportunities in sectors such as construction and road building. Tourism also seriously affected, with opportunities for work as porters and guides diminishing. In general, travel was reduced, as people were left to transport goods on their heads through the hills. This hits the lower class hardest as they used to dominate such jobs. Besides they were vulnerable to human or dangerous animals.

\subsubsection{Rural Exodus}

The main grassroots effects of the conflict have been: a rural exodus on the part of those mostly from the remoter areas; a significant reduction in travel and the transport of goods as a result of the lack of security; a disruption of many economic activities, with possible implications for food security in some areas; the destruction of local infrastructure (particularly that which is identified with government intervention and control); and the growth of a climate of fear and insecurity. It should be indicated the younger people left leaving farming which is the main source of production in the hands of the elders. This, resulting to poor or low output and a big generation gap which need to be filled in food production.

\subsubsection{Social Relationships}

Socially, relations were broken and inter marriage became a big problem between the villages concerned. Besides, self-trust and many tides were broken among a people who once confined in one another. During conflict, the social networks are disrupted and destroyed. This difficulty affect production since people carry out group or communal farming or give assistance to facilitate the task of farming. Resulting to such instability there are changes in family structures and composition as (El Jack, 2002) indicate. Gender relations can be subject to change since traditional division of labour within a family may be under pressure. War or conflict could go as far as disrupting or can even contribute to a complete breakdown of production - agricultural and industrial activities which adversely affects the country's economic output, exports and general viability. Many of the Third World countries emerging out of conflict are, therefore, compelled to adopt stabilization and Structural Adjustment Programmes (SAPs).

\subsubsection{Education}

Conflict results in decreased access to schools, preventing the opening of schools, threatening children's security while travelling to school and attending class and increasing teacher absenteeism. Access issues are also critical for refugee or internally displaced children, who may lack the appropriate documentation or language skills to participate in new schools (Shemyakina 2006,12). For children who do attend school, conflict can have a negative effect on educational 
attainment, increasing drop- out and reducing educational survival rates due to displacement, military recruitment or economic hardship. Educational attainment beyond primary suffers the most during conflict. Teachers from different parts of the country find it quite challenging as security was not certain, thus this gives room to prolong absenteeism.

\subsubsection{Ideology}

Notwithstanding that there is a wide spread assumption that poverty is a source of violence, despite there being no direct causal relationship between the two. Although today most violent conflicts take place in poor countries, they do not necessarily occur in the poorest of them nor are all poor countries involved in conflict. But even if this were the case that poverty is a source of conflict, there is now what is perceived as feminization of poverty, meaning that women are more to be found in poverty-stricken situations than men and that generally women are poorer than men. Research has shown that poverty and particularly extreme inequalities between rich and poor become sources of conflict where they are linked to the real or perceived oppression of a certain group (for example, social, religious, and ethnic) (Zuckerman and Greenberg, 2004). Thus, the state can be an instrument of discrimination and private enrichment in the hands of powerful elite and its followers. It can mediate between different interest groups through inclusive political processes and the redistribution of resources. Such an experience has led to a struggle for into village development and not clan interest as observed in the Ngie community.

Whereas the impact of external assistance on poverty cannot be underestimated, it has been argued that development assistance can contribute to stability when states use it to address human security needs, the political economy of conflict and inequality and discrimination and also for debt servicing as well as paying the state bureaucracy. However, it can also exacerbate conflict for example through supporting corruption or helping to perpetuate an unjust status quo or by putting too much emphasis on debt servicing. In addition, conditionality attached to development assistance for example structural adjustment policies (SAPs), can increase tensions particularly where without compensatory measures they require lay-offs in the public sector (Moser and Clark, 2002).

\section{Conclusion}

Although research activities about the Ngie culture are on the way with sequent and diversity fields, a global look at the findings to forge the community to an upward movement with an enabling capacity building for future prospects is very necessary. The pre-colonial as well as the colonial features should go together. Though not all about the colonial era had loopholes since their ideology was to promote development and progress which is a burden for community building but mishandled by some, maybe it was their method that made the ideas a problem. But even it was so our own contributions for personal interest, power warrant the poor state of affairs as we can see today. Thus, conflict could be seen in our analysis as a major socio-cultural heritage in many communities without leaving out the Ngie clan. Hence, the presence of a conflict of interest is independent of the occurrence of impropriety meanwhile, a conflict of interest can be discovered and voluntarily resolved before any corruption occurs. A widely used definition is: 'A conflict of interest is a set of circumstances that creates a risk that professional judgment or actions regarding a primary interest will be unduly influenced by a secondary interest.' Primary interest refers to the principal goals of the profession or activity, such as the protection of clients, the health of patients, the integrity of research, and the duties of public office. Secondary interest includes not only financial gain but also such motives as the desire for professional advancement and the wish to do favours for family and friends, but conflict of interest rules usually focus on financial relationships because they are relatively more objective, fungible, and quantifiable. The secondary interests are not treated as wrong in themselves, but become objectionable when they are believed to have greater weight than the primary interests. The conflict in a conflict of interest exists whether or not a particular individual is actually influenced by the secondary interest. It exists if the circumstances are reasonably believed (on the basis of past experience and objective evidence) to create a risk that decisions may be unduly influenced by secondary interests. In the nutshell a vivid description of the above conflict event is a portrait of cultural traits of the Ngie community which plays a role in the past and future of the people just like any other community.

\section{References}

i. Abebung and Andek respectively, pp.15-17, in Chief Tapong's Private Archives.

ii. Abebung Village, We Raise an Objection Mr. NCADA President An open letter to the President General of Ngie Cultural and Development Association, $4^{\text {the }}$ July 2010, p.3.

iii. Abong, 'Myth, History and the Throne of Andek from the Medieval to 1994', North West Regional Archives (NWRA) File NW/nd/1994/1/BK, p.4.

iv. Achebe Chinua 1964, Arrow of God. London: Heinemann.

v. Ambanasom, Son of the Native Soil, p.21.

vi. Ayong, P.M. 1993, Andek village: A sacrificial lamb for the Ngie identity, Buea.

vii. Azobi, V. A. 1979 'The Ngie Clan Area: Human Adaptation to Harsh Physical Environment', Doct oral du 3eme siècle, University of Yaounde, pp.104-105.

viii. Bartos, O.J. and Wehr, P. 2000 Using Conflict Theory, New York, Cambridge University press, p.10.

ix. Brock-Utne, Birgit, (1996): Peace Education in Post-Colonial Africa. Peabody Journal of Education. Vol. 71. No 3. pp.170-190.

x. By 1975, Ngie was still under the Mbengwi Central Sub Division. All matters in Ngie that caused dispute were handled by the administration in Mbengwi until 1992 when Ngie Sub Division was created. According to decree 
No 74/490 of $17^{\text {th }}$ May, 1974, the Senior Divisional Officers, as a matter of necessity, were charged to maintain law and order in their respective areas of jurisdiction.

xi. Collier and Lowe, V. 2000, The Settlement of Disputes in International Law: Institutions and Procedures, New York, Oxford University Press, p.24.

xii. File NW/la/ f.1956/4, Ngie Native Court Review AndoanoAbanyang of Angong V/S Ajugazum of Abebung, Claim Trespassing into Plantiffs Land, 'Court Case Abebung-Angong, 3 months ago.

xiii. Fisher, R. 2000, 'Sources of conflicts and methods of conflict resolution', School of International Service, the American University, p.1.

xiv. Fonteh, A.A 2009 'Agrarian crisis and the management of rural inter-ethnic conflict: some cases from the North West Region of Cameroon', in Conflict Prevention, Management and Resolution, Proceedings of the postgraduate Seminar Organized by the Faculty of Social and Management Sciences of the University of Buea, Cameroon, 28 January p.79.

xv. Hook, R. J.1940 Intelligent Report on the Ngie Clan: Reorganization of Clan area, NAB, File no 3060/Ab31b, p.2.

xvi. Hook, R.J. 1934, Intelligent Report on Ngie Clan, Bamenda Division Cameroon, NAB, Ab29 File No EP11390A, p.18.

xvii. http://www.en.wikipedia.org/wiki/conflict_resolution.

xviii. Ifang Promise A. 1998 'The Participation of Ngie Political Elite in the Political Life of Cameroon: 1961 to present day, Post Graduate Diploma (DIPES II) in History, Higher Teacher's Training College (ENS), Yaounde, 1999, p.11.

xix. Koffi Annan (1998) 'Responding to Situations of Conflicts'. United Nations 1998.May1996, p. 8)

$\mathrm{xx}$. In the commission report page 19, it is indicated that he (Pa Jacob Ajuazum) was the lone member of the 16-man delegation who did not sign the report findings.

xxi. Land Commission Report, p.3.

xxii. Land Dispute between Angong and Abebung, NWRA, File NW/vb/a.1975/2.

xxiii. Letter addressed to the DO of Ngie Sub Division, by Angong Traditional Council titled Destruction of Crops in Angong, 1997.

xxiv. Letter of Angong Church Authorities to the DO Ngie Sub Division Carrying details on the destruction of Presbyterian Church Akuwusowai by Abebung People, $4^{\text {th }}$ August 2000, in Chief Tapong's Private Archives.

xxv. Letter of Chief Tapong G. to the Momo Court of First Instance, $8^{\text {th }}$ June 1999, titled 'Dispute over Raffia Palm bush at Akuwusowai-Angong', in his private Archives.

xxvi. Rahim, M.A. \&Magner, N.R. (1995). Confirmatory factor analysis of the styles of handling interpersonal conflict: First-order factor model and its intervariance across groups. Journal of Applied Psychology, 80, 122-132.

xxvii. Schmid, A. (1997). 'Early Warning of Violent Conflicts' in A.Schmid (ed.), Violent Crime and Conflicts, Milan: ISPAC (International Scientific and Professional Advisory Council of the UN Crime Prevention and Criminal Justice Programme).

xxviii. Ting-Toomey, S. (1985). Toward a theory of conflict and culture. In W.B. Gudykunst, L.P. Stewart \& S. Ting-Toomey (Eds.). Communication Culture and Organization Processes, 71-85. Beverly Hills, CA: Sage.

xxix. Ufeigwei E. A. (2007), 'The Impact of colonialism on Ngie Traditional Authority', MA Dissertation in History, University of Yaounde 1, p.17.

xxx. Van de Vliert, E. (1996). Interventions in conflicts. In M. G. Schabruco, G.A.M. Winnbust\& C.L. Cooper (Eds.). Handbook of Work and Health Psychology. New York: Wiley \& Son, 405-425.

xxxi. Wanki, J. E. 'Revisiting Inter-Tribal Dissonance through Gender Lenses: A Comparative Review of Women as Agents, Victims, and Peace Negotiators in Selected Inter-tribal Conflicts in the North West of Cameroon', http://www.africapublisheronline.bogspot.com/2007/2/revisiting-inter-tribal-dissonace.htm.

xxxii. Wehrmann, B. 2008, Land conflicts: A practical guide to dealing with land disputes, Eschborn, Germany, Deutsche GesellschaftfürTechnischeZusammenarbeit (GTZ) GmbH.

xxxiii. Zuckerman, E. and M. Greenberg (2004) 'The Gender Dimensions of Post-Conflict Reconstruction: An Analytical Framework for Policymakers' in: Gender and Development Vol. 12, No. 3, 2004, Oxford. 